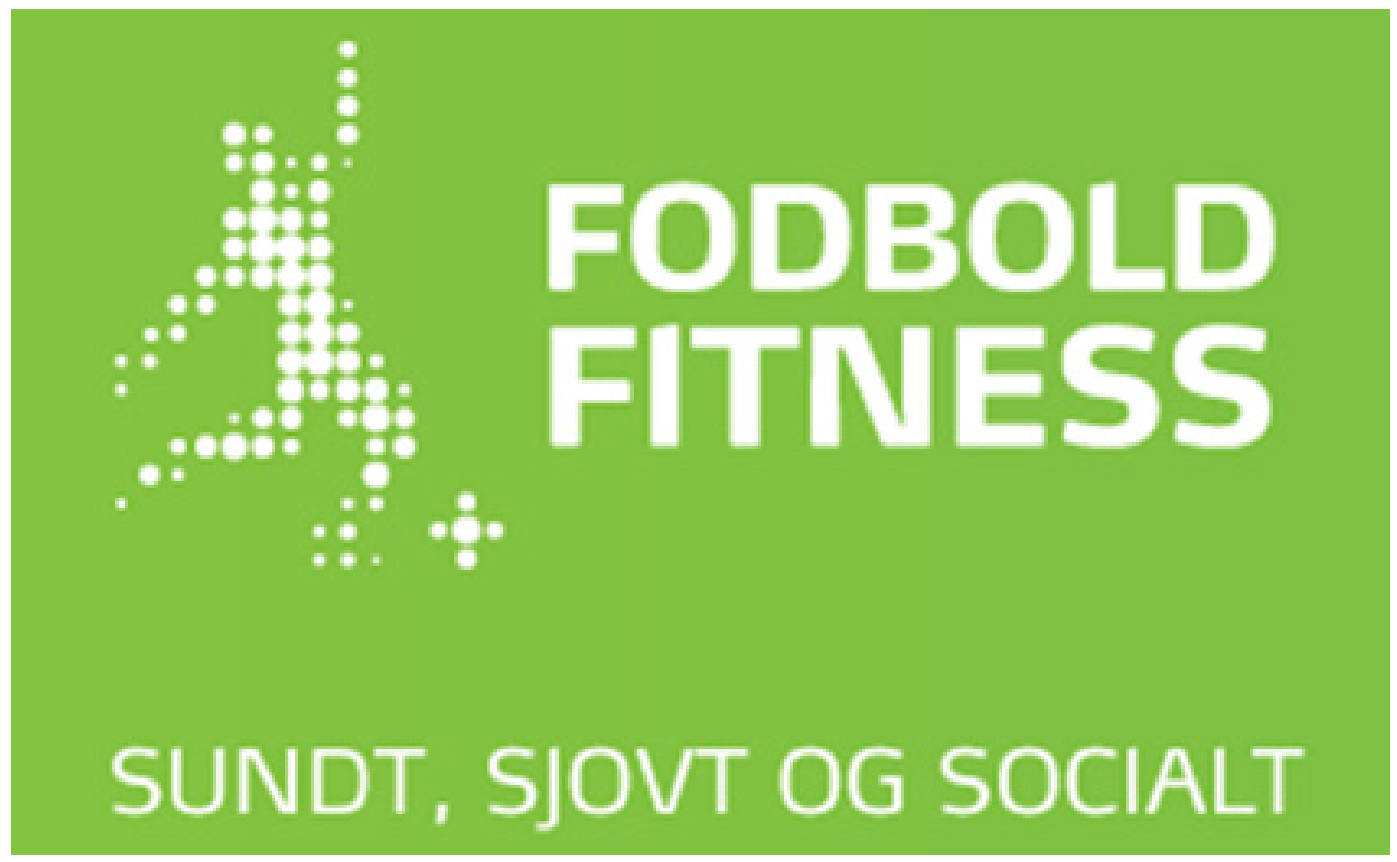

\title{
Fodbold Fitness
}

\section{Mere af det samme eller et brud med fritidsfodboldens sti?}

\section{SØREN BENNIKE ${ }^{1,2,3} \&$ LAILA OTTESEN ${ }^{2,3}$}

1) Dansk Boldspil-Union

2) Institut for Idræt og Ernæring, Københavns Universitet

3) Center for Holdspil og Sundhed, Institut for Idræt og Ernæring, Københavns Universitet

I denne artikel stilles der skarpt på Fodbold Fitness. Et initiativ som Dansk Boldspil-Union lancerer i 2011 som en reaktion på flere forskellige udviklingstendenser i det danske idrætsliv. Det gælder bl.a., at voksne (16 år+) danskeres idrætsvaner forandrer sig, ligesom der eksisterer et stigende politisk ønske om at inddrage foreningsidrætten i offentlige social- og sundhedsmæssige opgaver. DBU beskriver Fodbold Fitness som fodbold på en "sportslig og organisatorisk helt ny måde, der bryder med den traditionelle organisering, administration og medlemsstruktur”. Denne beskrivelse forfølges og udfordres i aktuelle artikel med udgangspunkt i teorien om stibrydende koncepter samt anvendelsen af dokumentstudier. Resultaterne af analysen viser, at Fodbold Fitness bryder med fritidsfodboldens sportslige form, men ikke med den organisatoriske form. Dette udfordres i artiklens diskussion, hvor det afslutningsvist konkluderes, at graden af brud afhænger af den enkelte klubs måde at forvalte Fodbold Fitness på. 


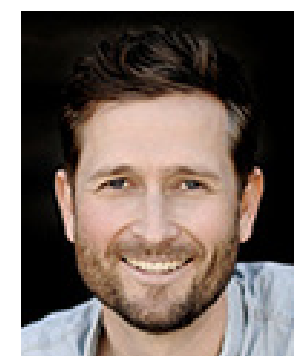

SØREN BENNIKE

Projektleder for 'Forskning og Viden'

Dansk Boldspil Union

sobe@dbu.dk

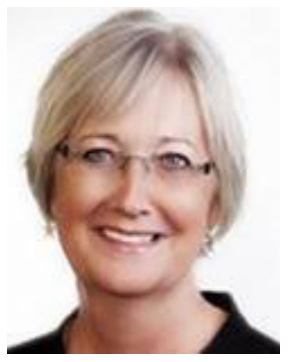

LAILA OTTESEN

Lektor

Institut for Idræt og Ernæring, KU

lottesen@nexs.ku.dk

\section{INDLEDNING}

I 2011 lancerer Dansk Boldspil-Union (DBU) Fodbold Fitness (FF) som en helt ny måde at organisere fodbold for voksne på, hvor fleksibilitet og sundhed er nøgleord. I en pressemeddelelse (DBU(a)) beskrives det, at projektet har til formål at udvikle og tilbyde fodbold på en "sportslig og organisatorisk helt ny måde, der bryder med den traditionelle organisering, administration og medlemsstruktur".

FF kan iagttages som en reaktion på flere tendenser i det danske idrætsliv. Det gælder bl.a., at voksne (16 år+) danskeres idrætsvaner forandrer sig. Efter en stødt stigende foreningsdeltagelse, siden man begyndte at måle på dette, er denne stagneret i perioden 2007-2011. Det til trods er det samlede antal idrætsaktive i samme periode steget. Det skyldes i særdeleshed den selvorganisede idræts stigende popularitet, herunder motionsløb og aktiviteter i fitnesscentre. (Laub, 2013) ${ }^{1}$. Fælles for disse aktiviteter er deres fleksible udøvelsesmuligheder, ligesom man kan argumentere for, at de indeholder et sundhedsfokus (Thing \& Ottesen, 2013). Samtidigt er den ældre del af befolkningen blevet mere aktive. Tidligere så man en klar sammenhæng mellem alder og idrætsdeltagelse således, at jo højere alder desto mindre idrætsaktivitet. Dette er ikke længere tilfældet, hvor en relativ stor procentdel af befolkningen er aktive stort set hele livet (Laub, 2013; Pilgaard \& Rask, 2016). Indenfor fodbold, som er denne artikels omdrejningspunkt, er det tilfældet,

1 Den seneste udgave af "Danskernes motions- og sportsvaner" viser at den samlede idrætsdeltagelse (16 år+) er faldet fra 64\% i 2011 til 61\% i 2016 (Pilgaard \& Rask, 2016:10). 
at andelen af voksne (16 år+) fodboldspillere har oplevet et mindre fald fra $10 \% \mathrm{i}$ 2007 til $9 \%$ i $2011^{2}$.

Foreningsidrætten står fortsat stærkt, men udviklingen indikerer også, at den står overfor nogle udfordringer. Disse bunder udover forandringer i idrætsvaner også i en tendens, hvor der eksisterer et stigende politisk ønske om at inddrage foreningsidrætten i offentlige social- og sundhedsmæssige opgaver (Forum for Idræt, 2011). Indenfor det idrætspolitiske felt er et godt eksempel seminaret "Fodbold Fitness som forebyggelse og behandling" organiseret af Danmarks Idrætsforbund (DIF), DBU og Center for Holdspil og Sundhed (CHS, 2013). Her bød næstformand i DIF, Preben Staun, velkommen med sætningen; "hvordan kan Fodbold Fitness blive en del af den kommunale sundhedspolitik?".

Også internationalt er disse tendenser at finde. Flere fremhæver at lande rundt om i Europa ligeledes oplever et statsligt ønske om, at den organiserede idræt skal spille en større rolle i velfærds- og sundhedspolitik (Houlihan, 2005; Bloyce \& Smith, 2010; Bergsgard et al., 2007), og flere undersøgelser tyder på, at fleksibilitet og sundhed spiller en rolle for valg af idrætsaktivitet (e.g. European Commission, 2014; Scheerder et al., 2011; Lamprecht et al., 2014; Tiessen-Raaphorst \& van den Dool, 2015). Med stor sandsynlighed vil disse lande opleve situationer, hvor idrætsforbund, ligesom det er tilfældet for DBU, vil reflektere over måden de tilbyder og organiserer traditionelle aktiviteter på. I en artikel af Karp et al. (2014) stilles skarpt på det svenske initiativ "Idrottslyftet", hvis primære formål er at udvikle ungdomsidrætten (7-25 år). Artiklen har den sigende titel, hvilket vi har ladet os inspirere af, "More of the same instead of qualitative leaps: A study of inertia in the Swedish sports system”, og understreger, at de aktiviteter, der igangsættes, ikke fører til udvikling og forandring som tiltænkt, men snarere er medskaber af inerti. I forlængelse heraf stilles der i denne artikel følgende spørgsmål: Bryder Fodbold Fitness med fritidsfodboldens sti (Sydow et al, 2005), og i så fald hvordan?

Det følgende indledes med et afsnit, der behandler artiklens metodiske fremgangsmåde. Dernæst følger en analyse, der stiller skarpt på FF i relation til fritidsfodbold og professionel fodbold. Afslutningsvist diskuteres implementeringen af FF med udgangspunkt i analysens resultater og eksisterende forskning på området. Dette afsnit fungerer også som artiklens konklusion.

2 Den seneste udgave af "Danskernes motions- og sportsvaner" viser at andelen af voksne fodboldspillere er faldet til 7\% i 2016 (Pilgaard \& Rask, 2016:44) 


\section{METODE OG TEORI}

Denne artikel er en del af et større forskningsprojekt, der igennem en årrække har fulgt udviklingen og implementeringen af FF og analyseret samt diskuteret denne fra flere forskellige teoretiske perspektiver (Bennike et al., 2014a; Bennike et al., 2014b; Bennike, 2016; Bennike \& Ottesen, 2016; Thing et al., 2016; Ottesen et al., 2017; Thing \& Ottesen, 2018; Pedersen et al., 2019; Thing et al., 2019; Bennike et al., 2019a, Bennike et al., 2019b). I den henseende er der i stort omfang blevet gennemført litteraturstudier, dokumentanalyser, spørgeskemaundersøgelser, interviews, fokusgruppeinterviews og observationer.

Den empiri, der ligger til grund for denne artikel, er baseret på 4 dokumenter dateret 2010 og 2011, alle med DBU som afsender; (DBU(a), DBU(b), DBU(c) og DBU(d)). Disse er indsamlet i perioden 1. oktober 2012 - 1. juni 2013 og strategisk udvalgt, eftersom de kan belyse, hvorfor FF præsenteres, og hvilke rammer det skal foregå i. I forhold til dokument 'DBU(b)', der kan karakteriseres som et primært dokument (Lynggaard, 2010), er der tale om et internt dokument rettet mod modtagere med beslutningskompetence, der kan afgøre om FF skal igangsættes eller ej. I forhold til de øvrige er der tale om sekundære dokumenter (Lynggaard, 2010), hvor de mulige modtagere er enkeltindivider, frivillige fodboldklubber, kommuner og andre med interesse for FF. Dokumenterne er blevet samlet og kodet efter pre-definerede temaer (Creswell, 2007) genereret ud fra forskningsspørgsmålet og det teoretiske perspektiv. Det gælder hhv. organisation og form samt teorien om stibrydende koncepter, herunder det kognitive element, det emotionelle element, det sociale element og det ressourcemæssige element.

\section{Teorien om stibrydende koncepter}

For at kunne præsentere teorien om stibrydende koncepter, skal man nødvendigvis præsentere begrebet stiafhængighed (path dependence) (Mahoney, 2000; Campbell, 2004; Sydow et al., 2005). Noget forsimplet dækker dette over, at den beslutning, der tages i dag, er påvirket af den beslutning, der blev taget i går. Over tid fastlåses man på en bestemt sti og i en bestemt måde at gøre tingene på. Dette kan der være mange forklaringer på (Mahoney, 2000; Campbell, 2004; Sydow et al., 2005), hvor flere givetvis spiller en rolle samtidigt. For det første har en sti ofte været problemfyldt at skabe, hvilket hæmmer lysten og ønsket om forandring. For det andet eksisterer der i mange tilfælde lovmæssigheder, der ofte besværliggør forandringer. Og for det tredje skabes og tilegnes viden om, hvordan man skal agere inden for stien. Nedenstående figur illustrerer, hvordan den klassiske forståelse af stiafhængighed kan iagttages som et faseforløb bestående af tre faser. 
Figur 1: Tre faser i den klassiske forståelse af stiafhængighed (Sydow et al., 2005)

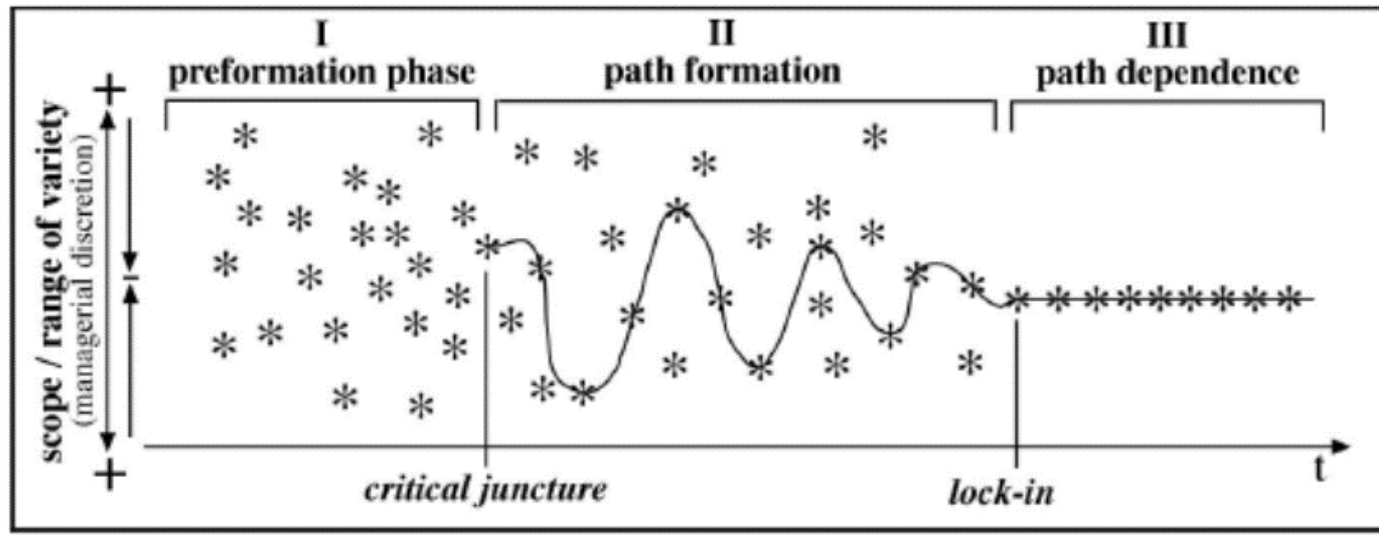

I den første fase, kaldet preformation phase, er et valg ikke præget af tidligere handlinger. Men når dette valg træffes, igangsættes en proces, hvor graden af valgfrihed langsomt indsnævres. Dette tidspunkt betegnes som a critical juncture, hvilket skaber overgangen til anden fase - path formation. At det betegnes som kritisk understreger, at når dette valg føres ud i livet, bliver det svært at returnere til udgangspunktet, og stien forstærkes med tiden. Ved indtrædelsen til tredje fase opleves et lock-in, der markerer overgangen til path dependence. Nu er stien låst, og den vil blive fulgt, ligesom et tog der følger skinnerne i en bestemt retning.

Sydow et al. (2005) kritiserer denne forståelse som værende for deterministisk og præsenterer teorien om stibrydende koncepter. Denne kritik samt stibrud og skabelsen af nye stier er illustreret i figur 2. For det første argumenterer Sydow et al. for, at den første fase ikke kan sige sig fri fra en historisk kontekst, der skaber begrænset valgfrihed. Ligesom der foretages nogle mere eller mindre intentionelle valg og fravalg frem mod the of point critical juncture. Dette illustreres med den grå markering. I stedet for preformation phase betegner Sydow et al. denne for generating momentum. Herefter foretages valgene på baggrund af, hvad der betegnes som positive feedback, førend der opleves et lock-in. Denne fase betegnes path shaping. Dette lock-in, der markerer overgangen til path-dependence skal ikke opfattes deterministisk i den forstand, at det ikke er muligt at bryde den sti, der er grundlagt. I stedet betegnes markeringen i tredje fase som en restricting corridor (Sydow et al., 2005), som et billede på, at når man går denne vej, synes valgene begrænsede og begrænsende. Som det fremgår, tilføjes endnu en fase i forhold til figur 1. Denne fase betegnes path breaking (Sydow et al., 2005) og illustrerer hvordan et brud initieres ved un-locking (Sydow et al., 2005), hvilket skaber en proces, hvor der igen åbnes gradvist for valgmuligheder. Og således vil processen begynde på ny. Når en ny sti skabes, kan den gamle sti imidlertid godt fortsætte, hvilket vil blive eksemplificeret i artiklens analyse. 
Figur 2: Stibrud og skabelsen af nye stier (Sydow et al. 2005:32)

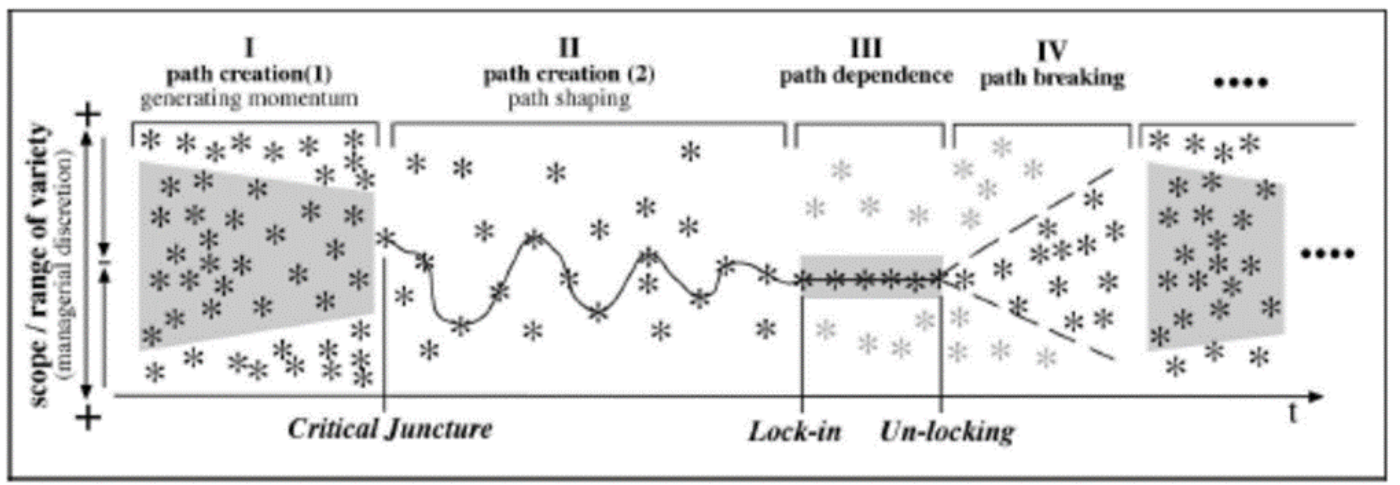

I forlængelse af ovenstående er det helt centralt at stille spørgsmålet: Hvordan brydes stien, og hvordan generes momentum til grundlæggelsen af en ny? Sydow et al. (2005:25) præsenterer nedenstående tabel og argumenterer for fire elementer, der er med til både at bryde med, men også skabe stiafhængighed. Det gælder hhv. et kognitivt, et emotionelt, et socialt og et ressourcemæssigt element.

\section{De fire elementer}

Det kognitive element indeholder selvforstærkende blind spots, der gør det svært at være kritisk reflekterende over den diskurs, der hersker. Det kan være svært at se, hvad man ikke kan/vil se. Dette fremgår i tabel 1 og betegnes som reflection trap. At kunne identificere og påpege kritiske forhold i den eksisterende diskurs er et vigtigt skridt på vejen mod at bryde stiafhængighed. Her er det fordelagtigt at få nye perspektiver på situationen og tilegne sig ny viden, måske med eksterne øjne. I tabel 1 eksemplificeres dette som ekstern konsulent. Det emotionelle element handler om adfærd knyttet til følelser, engagement og identitet, der er skaber af rutiner. Eksempelvis kan den energi, der skabes som følge af engagement, blive en identitet, og jo større engagement - des stærkere identitet. I tabellen betegnes dette som commitment trap. For at bryde stiafhængighed kræver det at adfærdsmæssige rutiner baseret på følelser irriteres. Det gælder særligt de følelser, der er knyttet til det fællesskab, der eksisterer. Det sociale element lægger sig tæt op ad dette og handler om, at der skabes en selvforstærkende norm og en antagelse om, at måden, tingene gøres på, er de rigtige, fordi sådan har man altid gjort. I tabellen betegnes det som normative trap. For at bryde stiafhængighed kræves det, at denne norm gentagne gange bliver udfordret og irritereret. Det ressourcemæssige element knytter sig både til frygten for at tabe ressourcer og nødvendigheden af at besidde og/eller omfordele ressourcer. I tabellen betegnes det som sunk cost trap. For at bryde stiafhængighed er det nødvendigt ikke at lade sig styre af denne frygt 
og samtidig være bevidst om, at det koster ressourcer at bryde stien. Helt overordnet gælder det om at skabe et forandringsmomentum baseret på disse elementer, der er stærkt nok til "at fă toget til at skifte spor". Sydow et al. (2005:23) skriver, at det handler om "unfreezing fixated patterns and routines"

Tabel 1: 4 elementer for sti-brydende koncepter. (Sydow et al., 2005:25)

\begin{tabular}{|l|l|l|}
\hline Element & Kilder til stiafhængighed & Tilgange til stibrydende koncepter \\
\hline $\begin{array}{l}\text { Det kognitive } \\
\text { element }\end{array}$ & $\begin{array}{l}\text { Selvforstærkende "blind-spots". } \\
\text { "reflection trap" }\end{array}$ & $\begin{array}{l}\text { Se den organisatoriske diskurs, ny } \\
\text { viden/perspektiver fx suppleret af } \\
\text { informationer fra en ekstern konsulent. }\end{array}$ \\
\hline $\begin{array}{l}\text { Det emotionelle } \\
\text { element }\end{array}$ & $\begin{array}{l}\text { Selvforstærkende eller } \\
\text { eskalerende engagement. } \\
\text { "Commitment (or identity) } \\
\text { trap" }\end{array}$ & $\begin{array}{l}\text { Adfærdsmæssige interventioner } \\
\text { hovedsageligt på gruppeniveau. }\end{array}$ \\
\hline Det sociale element & $\begin{array}{l}\text { Selvforstærkende normer, } \\
\text { standarder og antagelser. } \\
\text { "Normative (or cultural) trap" }\end{array}$ & $\begin{array}{l}\text { Systematiske interventioner der } \\
\text { irriterer the sociale system og bryder } \\
\text { rutiner og mønstre }\end{array}$ \\
\hline $\begin{array}{l}\text { Det } \\
\text { ressourcemæssige } \\
\text { element }\end{array}$ & $\begin{array}{l}\text { Selvforstærkende } \\
\text { ressourceallokering. } \\
\text { "sunk cost trap" }\end{array}$ & $\begin{array}{l}\text { Omallokering af ressourcer i forhold til } \\
\text { herskende kognitive og normative } \\
\text { regler. }\end{array}$ \\
\hline
\end{tabular}

\section{ANALYSE: FODBOLD FITNESS - EN NY STI?}

I det følgende forfølges påstanden jf. indledningen om, at FF er en helt ny måde at organisere fodbold for voksne på (DBU(a)). Dette gør vi ved at analysere hvorledes FF adskiller sig organisatorisk og spilmæssigt fra to andre former for fodbold, der organiseres under DBU, hhv. fritidsfodbold og professionel fodbold, samt belyse det forandringsmomentum, der leder op til lanceringen af FF, med udgangspunkt i teorien om stibrydende koncepter (Sydow et al. 2005). Men inden da defineres hhv. fritidsfodbold og professionel fodbold samt det forandringsmomentum, der ledte op til indførelsen af professionel fodbold.

Fritidsfodboldtermen, som den benyttes her, knytter sig til en praksis, hvor man træner i sin fritid og deltager i en turneringsstruktur med kamp i weekenden. At spillet organiseres i foreninger betyder, at organisationen bag er non-profit modtager offentlig støtte og har en demokratisk organisationsstruktur, hvor deltagerne betaler et medlemskontingent. Som spiller er man en del af et hold, der indgår i en turneringsstruktur med regionale/nationale regler ofte tæt knyttet til spillets internationale regelsæt. Ofte vil turneringsstrukturen og fokus på denne, 
alt afhængig af niveau, betyde, at spillet også indeholder et konkurrenceelement og et fokus på spilmæssig præstationsoptimering. De fordelagtige lovmæssige vilkår for foreningsdannelse i Danmark har sammen med stærke amatøristiske idealer bidraget til anlæggelsen af en særdeles stærk sti, der har eksisteret i mere end 130 år (Bennike et al., 2019b).

\section{Professionel fodbold - et brud med fritidsfodbold}

Tæt på 100 år efter, spillet første gang blev organiseret i en forening, sker der et brud med fritidsfodbolden. Helt centralt er året 1978, hvor DBU efter længere tids pres opgiver amatøridealet (Grønkjær \& Olsen, 2007). De klubber, der konkurrerede på højeste niveau, forandrede derfra gradvist deres organisatoriske system, og flere klubber dannede professionelle overbygninger i form af profitorienterede anpartsselskaber. I dag er de klubber, der forvalter professionel fodbold på højeste niveau, markedsorienterede, privatiserede og har en hierarkisk organisatorisk opbygning (Gammelsæter \& Senaux, 2011; Bennike et al., 2019b). Spillerne er ansatte, og kampene følger internationalt definerede regler. Spillet ligner til dels det spil, der foregår i fritidsfodbold, men organisationen bag er markant anderledes. Disse forskelle i karakteristika er opsummeret i figur 3.

Med udgangspunkt i teorien om stibrydende koncepter eksisterer ved indførelsen af professionel fodbold et forandringsmomentum, hvor alle fire elementer løbende var blevet udfordret og irriteret i relativ voldsom grad. I tiden op til 1978, blev DBU's opfattelse af amatøridealet kraftigt kritiseret. Særligt med udgangspunkt i dansk fodbolds konkurrenceevne. DBU var godt klar over disse udfordringer, og de var bevidste om muligheden om at professionalisere fodbolden. De var ikke offer for såkaldte blind spots jf. tabel 1. Alligevel var det svært at bryde med det emotionelle og sociale element knyttet amatøridealet, hvilket tilbageholdt beslutningen i flere år. Eksempelvis anså DBU de spillere, der i udlandet tog penge for at spille fodbold, som "landsforrædere", der ikke passede til den danske mentalitet (Grønkjær \& Olsen, 2007:158). Dermed kunne de heller ikke deltage på det danske landshold. Sidenhen tillod DBU max. 5 professionelle spillere på landsholdet, og de indførte et gaveregulativ, så divisionsklubberne kunne præmiere deres spillere med forbrugsgoder (Grønkjær \& Olsen, 2007). Gaveregulativet kan ses som en afgørende begivenhed i forhold til et point of critical juncture frem mod et lock-in og dermed en konsolidering af den professionelle sti i 1978. Samtidigt var DBU som organisation blevet professionaliseret i en sådan grad, at ressourcerne til at foretage et brud med fritidsfodbolden var til stede. Gradvist blev der altså oparbejdet et forandringsmomentum stærkt nok til, at en ny sti blev skabt, hvor særligt klubbens organisatoriske form adskiller hhv. fritidsfodbold og professionel fodbold. 


\section{Fodbold Fitness - et nyt brud med fritidsfodbolden}

I et internt dokument dateret 2010 (DBU(b)), der omhandler udviklingen af FF, står bl.a., at de primære formål er at:

"rekruttere flere voksne motionsfodboldspillere til de organiserede klubber, profilere fodbold som en sundhedsfremmende aktivitet (...), skabe interesse for at bruge fodbold som træning (ingen turneringsstruktur) (...) og støtte klubberne $i$ at skabe mere fleksibilitet $i$ tilbuddene til de voksne motionsfodboldspillere."

Denne beskrivelse udfoldes yderligere i den første FF-folder (DBU(c)), som DBU præsenterer på deres hjemmeside i begyndelsen af 2011:

"DBU introducerer nu FF, som er inspireret af det sociale og sjove fra fodbolden og fitnesscentrenes fleksibilitet. (...) Fodbold er den bedste kombinationstræning og meget effektiv til forebyggelse af livstilssygdomme. (...) Det (FF) er motionsfodbold med ligesindede, når det passer dig og fokus er på motion, sjov og sammenhold. FF skal være et tilbud i eksisterende fodboldklubber til de (...) som gerne vil spille fodbold, men som ikke har tid og lyst til at spille $i$ de traditionelle rammer med træning flere gange om ugen og kamp på bestemte tidspunkter. (...) (FF er) altid med bold og på mindre baner, så hver enkelt spiller fär flere boldberøringer og er en større del af spillet. En decideret træner er ikke nødvendig, ligesom fodboldspillet kan kombineres med fx fitnessøvelser, hvis deltagerne ønsker at træne hele kroppen. Fodbold er en effektiv træningsform til at forbedre sundheden og den fysiske form og er en bedre kombinationstræning end løb eller styrketræning. Derudover skabes der relationer på fodboldbanen, som betyder, at det er nemmere at holde fast i din nye vane."

Med det formål at forstå aktiviteten i relation til hhv. fritidsfodbold og professionel fodbold bør tre aspekter fremhæves som karakteristiske for FF. For det første skal det organiseres af eksisterende klubber (foreninger), der i forvejen organiserer fritidsfodbold. For det andet findes et italesat sundhedsperspektiv. Og for det tredje findes der ingen turneringsstruktur.

Det værd at hæfte sig ved, at FF ikke har rod i samme eksplicitte ønske fra omgivelserne, som det var tilfældet ved indførelsen af professionel fodbold, hvor DBU som nævnt i en årrække kæmpede imod. Ved indførelsen af FF er det derimod DBU selv der præsenterer idéen. Dette er imidlertid ikke ensbetydende med, at FF så at sige kommer ud af den blå luft, eftersom flere forhold kan iagttages som førende op til et forandringsmomentum og dermed have udfordret og irriteret den eksisterende sti (fritidsfodbold). Det gælder bl.a. forandringer i danskernes idrætsvaner, 
herunder nødvendigvis fodbold. I det interne oplæg (DBU(b)) omhandlende FF præsenteres nedenstående citat fra Idan (2010):

"Danske fodboldklubber må i gang med at udvikle voksenfodbolden. (...) efter de tidlige barneår er fodboldklubber verdensmestre $i$ at udvikle talenter - og afvikle de mindre dygtige spillere. Teenagere og voksne forlader fodboldklubberne i rå mængder og drøner ud på løbestierne og ind $i$ fitnesscentrene for at dyrke aktiviteter. (...) først og fremmest må forklaringen være, at fodboldklubberne ikke evner at organisere en fodboldtræning, som befolkningen har lyst til og mulighed for at deltage i efter de første børne- og ungdomsår".

I samspil med tabeller, der viser at fodbold er en yderst populær børneidræt, hvorefter populariteten sættes over styr, er Idans citat, jf. tabel 1 en ekstern konsulent, der synliggør kritiske forhold i den eksisterende organisatoriske diskurs.

I det interne oplæg nævnes også udenlandske "pay'n'play"3 scenarier og det danske fodboldcenter "Fodboldfabrikken". Disse står som eksempler på kommercielle aktører, der kunne påtage sig rollen som udbyder af en fleksibel form for motionsfodbold. Her understreges det, at hvis ikke FF lykkes, kan DBU "se frem til langt større konkurrence fra andre udbydere af motionsfodbold på det danske marked i fremtiden" - hvis det derimod lykkes, "ligger der endog meget store medlemsmæssige gevinster forude, med dertilhørende kontingentindtægter for fodboldklubberne". Disse forhold er jf. tabel 1 med til at udfordre reflection trap. Samtidigt er der i årene op til FF blevet publiceret en lang række studier, der leverer 'ny viden', der underbygger sammenhængen mellem fodbold og sundhed (SJMS, 2010). Dertil bør man også fremhæve DBU's nationale strategi for videreudviklingen af dansk fodbold fra 2010 (DBU(d)), hvor der bl.a. står:

"Fodboldens position som landets mest attraktive holdsport baseret på markedsandele skal fastholdes og udbygges. (...) Nøgleordet er fleksibilitet $i$ tilmelding og udøvelse. Tiltrækningen, udviklingen og fastholdelsen af spillere skal ske gennem tilbud af relevante og tidssvarende fodboldaktiviteter af høj kvalitet, uanset spillernes individuelle potentiale og ambitioner. (...) Den brede opfattelse affodbold som en unik holdsport (...) skal linkes til fodboldens sundhedsmæssige betydning, (og) fodboldens betydning for udviklingen af sociale kompetencer."

3 Direkte oversat betyder det "betal og spil". Det vil sige, at en kunde betaler et beløb og får adgang til faciliteter. Et eksempel herpå er Fodbold Fabrikken (Fodbold Fabrikken, 2019), hvor en gruppe spillere betaler en privat aktør for adgangen til en fodboldbane. 
Strategien, der med ovenstående citat i nogen grad står som skelettet til FF, kan jf. figur 2 ses som et point of critical juncture. Her udfordres den identitet, der knyttes til fodbold som en konkurrencesport, hvor et selvforstærkende fokus er at træne med det formål at klare sig godt i weekendens kamp. I strategien skrives eksplicit om fleksibilitet og sundhed, og der lægges op til, at nogle adfærdsmæssige rutiner skal udfordres. I den henseende bør aktiviteterne futsal, beach soccer, street football og panna også nævnes som aktiviteter i DBU, der i forhold til at re-tænke spillets form irriterer den selvforstærkende norm (jf. tabel 1), der eksisterer i fritidsfodbolden. Sidst men ikke mindst skal det understreges, at igangsættelsen af FF ikke påvirker DBU's driftsbudget. FF støttes af DIF med godt 2,7 mio. kr. (DBU(a)) og 1,8 mio. kr. fra det, der betegnes DBU's udviklingspulje. ${ }^{4}$ I relation til det ressourcemæssige element jf. tabel 1 skal DBU altså ikke frygte at tabe eller omfordele ressourcer for at skifte sti og de er dermed ikke offer for sunk cost trap. Hertil skal det nævnes, at tanken på sigt er, at FF skal blive selvkørende i lokale klubber (Bennike, 2016).

I modsætning til den professionelle sti bryder FF ikke med fritidsfodboldens organisatoriske form, eftersom aktiviteterne skal organiseres af eksisterende klubber (foreninger). Derimod synes FF at bryde med fritidsfodboldens sportslige form, hvor turneringselementet er i fokus. I stedet sættes træning i fokus. Sidstnævnte er helt afgørende, eftersom det muliggør, at de enkelte FF-hold kan spille efter deres egne regler (se fx Bennike, 2016). Dette er forsøgt indfanget i nedenstående figur.

Figur 3: 3 former for organiseret fodbold

\begin{tabular}{|c|c|c|c|}
\hline $\begin{array}{l}3 \text { former for } \\
\text { organiseret } \\
\text { fodbold }\end{array}$ & $\begin{array}{l}\text { Professionel fodbold } \\
\text { (1978) }\end{array}$ & $\begin{array}{l}\text { Fritidsfodbold } \\
\qquad(1879)\end{array}$ & Fodbold Fitness \\
\hline $\begin{array}{l}\text { Klubbens } \\
\text { organisatoriske } \\
\text { form }\end{array}$ & $\begin{array}{l}\text { For-profit } \\
\text { Privat støtte } \\
\text { Hierarkisk organiseret } \\
\text { Ingen medlemskontingent (job) }\end{array}$ & $\begin{array}{l}\text { Non-profit } \\
\text { Offentlig støtte } \\
\text { Demokratisk organiseret } \\
\text { Medlemskontingent }\end{array}$ & $\begin{array}{l}\text { Non-profit } \\
\text { Offentlig støtte } \\
\text { Demokratisk organiseret } \\
\text { Medlemskontingent }\end{array}$ \\
\hline $\begin{array}{l}\text { Spillets } \\
\text { sportslige form }\end{array}$ & $\begin{array}{l}\text { Forbedre færdigheder } \\
\text { Internationale regler } \\
\text { Turnering }\end{array}$ & $\begin{array}{l}\text { Forbedre færdigheder } \\
\text { (inter)Nationale regler } \\
\text { Turnering }\end{array}$ & $\begin{array}{l}\text { Forbedre sundhed } \\
\text { Lokale regler } \\
\text { Ingen turnering }\end{array}$ \\
\hline
\end{tabular}

4 I januar 2014 bliver der indgået et fireårigt samarbejde mellem DBU, DIF og Nordea-fonden, der sikrer yderligere 6,345 mio. kroner til arbejdet med FF frem til udgangen af 2017. Nordea-fonden bidrager med 3,5 mio., DBU bidrager med 1,845 mio. og DIF bidrager med 1 mio. der fungerer som en del af DIF’s medfinansiering af DBU’s fireårige kommunestrategi (DBU, 2014). 


\section{DISKUSSION OG AFRUNDING}

Som berørt i indledningen har den svenske foreningsidræt intentioner om at udvikle ungdomsidrætten (Karp et al., 2014). Til trods for at FF-målgruppen er voksne, kan der alligevel drages nogle interessante paralleller. I en artikel af Fahlén et al. (2015) noterer forfatterne, at man i Sverige har opstillet et scenarie, hvor idrætsforeninger kan søge midler til initiativer, der har det ønskede fokus - i dette tilfælde ligestilling i relation til køn og klasse. I forlængelse heraf konkluderer forfatterne, at med denne form 'skubbes' udviklingsopgaven videre til idrætsforeninger, der står med et ansvar, som de hverken har bedt om eller accepteret. I relation hertil tegner flere undersøgelser et billede af, at der ej heller eksisterer et ønske om at løfte dette ansvar, eftersom foreningerne overvejende er orienteret imod deres kerneaktivitet (se fx Nichols \& James, 2008). Her forstås den aktivitet der dyrkes - eksempelvis fritidsfodbold. Karp et al. (2014) har ligeledes stillet skarpt på det svenske scenarie og konkluderer, at der overvejende bliver bevilget støtte til initiativer, der omhandler rekruttering. Således bidrager de gennemførte aktiviteter ikke til udvikling af aktiviteter, men snarere til inerti og konsolidering af den eksisterende sti. I modsætning hertil er FF et initiativ, hvor DBU ikke 'skubber videre', men derimod intentionelt forsøger at igangsætte en forandring og dermed udfordre den etablerede sti og dennes inerti. Det bliver gjort i en form, hvor DBU sætter rammerne, for at fodboldspillets sportslige form udvikler og forandrer sig med ønsket om at involvere en ny målgruppe og dermed reagere på en potentiel trussel fra kommercielle udbydere.

I relation til implementeringen af såkaldte top-down initiativer, hvilket man i nogen henseender kan argumentere for, at FF er (Bennike, 2016), skriver Vail (2007:571), at det essentielle er lokalsamfundets behov og ikke den pågældende aktivitet (kerneaktivitet):

“(..) top-down initiatives that ignore community needs have not succeeded in sustaining sport participation. (...) Traditional strategies to address sport participation ignore the complexity of the problem of declining participation in sport and overlook a fundamental principle of participation - community development."

Vails pointe angående lokalsamfundets behov er interessant i forhold til implementeringen af FF. I analysen ovenfor fremgår det, at FF bryder med fritidsfodboldens sti (kerneaktiviteten), særligt eftersom der ikke eksisterer en turneringsstruktur. Hvis man tager det forhold i betragtning, at klubberne kun har øje for kerneaktiviteten, vil man forudsige implementeringsmæssige vanskeligheder, der knytter sig til klubbernes manglende interesse. Her er det dog en væsentlig pointe, at FF er plastisk, forstået på den måde at klubberne kan organisere det i en form, 
der passer dem, inden for den ramme som opstilles. Her er der netop plads til lokalsamfundets behov i langt højere grad, end det er tilfældet for fritidsfodbold. Og samtidigt er der plads til klubbens behov. Bennike og Ottesen har ved casestudier fulgt den lokale implementering og organisering af FF i fire klubber (Bennike, 2016). I særligt to cases distancerer FF sig åbenlyst fra fritidsfodbolden, men ikke fra lokalsamfundets behov, hvilket et stigende antal FF-deltagere bevidner. Disse klubber er blot to af mange hundrede, der i dag organiserer FF, hvilket også må udfordre en rigid forståelse af fritidsfodbolden som fodboldklubbers kernaktivitet, såfremt denne findes. Noget tyder på at kerneaktiviteten ikke kan defineres helt så simpelt, og at denne kan indeholde flere konventioner (Skille, 2011), underforstået flere stier.

Når det er sagt, kan man ikke negligere fritidsfodboldens betydning med de normer og værdier, der eksisterer heri. Det gælder særligt i en case, hvor den FF-aktivitet, der foregår, til forveksling ligner fritidsfold, dog med den helt centrale forskel at holdet ikke deltager i turnering (Bennike, 2016). Hertil skal det nævnes, at flere af de spillere der deltager, spiller på andre af klubbens turneringsaktive hold (Bennike, 2016). I nogen grad betyder det, at spillets sportslige form ikke har karakter af det stibrud, der jf. analysen eksisterer. Dette som følge af netop stiafhængighed, hvor FF trods de relativt frie organisatoriske rammer i dette tilfælde læner sig op ad fritidsfodbolden. Denne udfordring findes ifølge Bennike \& Ottesen overvejende for FF hold, hvor deltagerne allerede spiller og/eller har spillet fritidsfodbold, hvilket ofte er tilfældet for mænd (Bennike, 2016). Et andet godt eksempel på, at stien er svær at bryde, er at nogle klubber i samarbejde med DBU har taget initiativ til at arrangere FF-stævneaktiviteter, så der eksisterer en mulighed for at konkurrere mod andre klubber. Afholdelsen af stævner kræver ensrettede regler, og de deltagende hold ønsker (muligvis) at vinde og vil derfor træne med det formål at præstationsoptimere. Det betyder at FF nærmer sig fritidsfodbold, hvor turneringen forbliver et bærende element. Der er dog tale om en turnering i stævneform, der afsluttes i løbet af nogle timer, og ikke en turnering over en længerevarende periode, som det er tilfældet i fritidsfodbold. Det til trods vil initiativet vedr. stævner reducere det brud i spillets form, som analysen påpeger, og potentielt vil man få "mere af det samme". I det lys og med tanke på at klubberne kan organisere FF i en form, der passer dem, kan de selv afgøre, i hvor høj grad aktiviteten bryder med fritidsfodboldens sti. Heri findes både en implementeringsmæssig fordel, men også en udfordring. Med en analogi til IT så er FF en ny version af fodbold, som klubberne kan "downloade" og anvende i en form, der passer til dem, hvis de har interessen. Hertil kan man tilføje, med reference til Vail (2007), at aktiviteten kun bliver succesfuld, såfremt den passer til lokalsamfundets behov. Som Skille (2008:185) skriver: "The outcome of a specific programme always depends on the grassroots implementer". Med FF har DBU skabt rammerne for, at klubberne 
i højere grad, end hvad der er tilfældet i fritidsfodbolden, kan skabe sammenhængen mellem lokalsamfundets behov og klubbens aktiviteter. I nogle tilfælde vil det bryde med fritidsfodboldens sti, og i andre tilfælde vil det ikke.

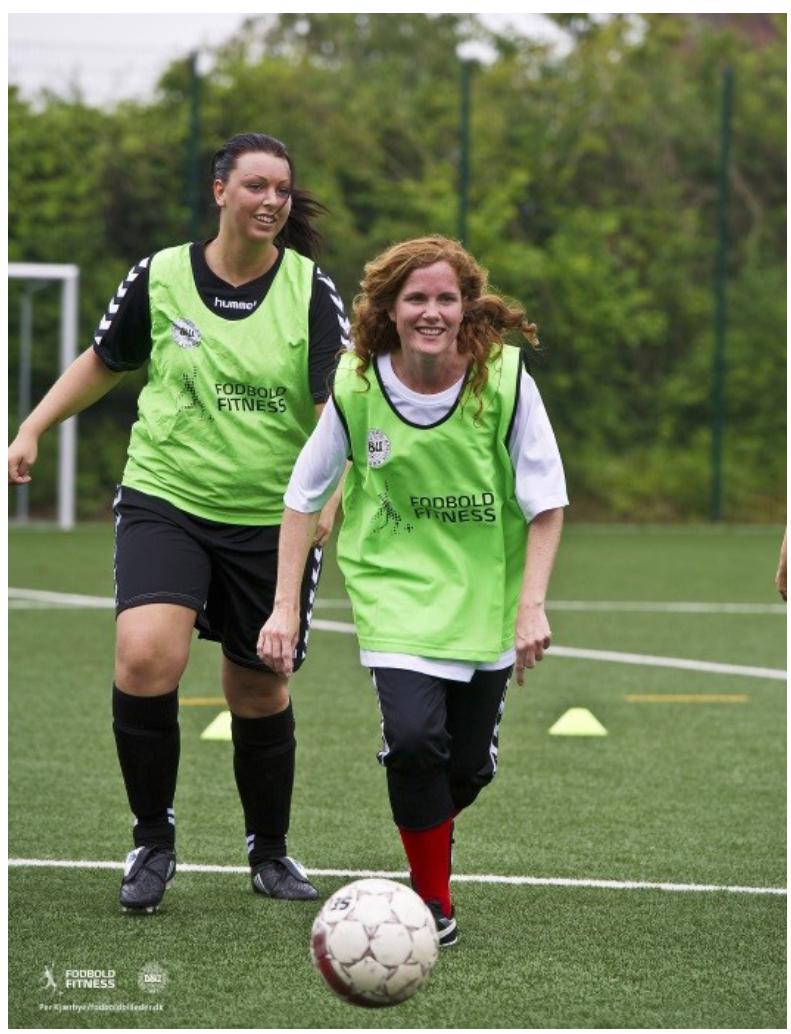

\section{REFERENCER}

Bennike, S., Wikman, J. M. \& Ottesen, L. (2014a): Fodbold Fitness - Implementeringsstudie. 2013. Center For Holdspil og Sundhed. Institut for Idræt og Ernæring. Københavns Universitet.

Bennike, S., Wikman, J.M., Ottesen, L. (2014b): Football Fitness - a new version of football? A concept for adult players in Danish football clubs. Scand J Med Sci Sports 2014: 24 (suppl. 1): 138-146. DOI:10.1111/sms.12276

Bennike, S. (2016). Fodbold Fitness - implementeringen af en ny fodboldkultur. PH.D. Afhandling. University of Copenhagen. Faculty of Science. SL grafik, Frederiksberg C, Denmark. 
Bennike, S. \& Ottesen, L. (2016). How does interorganisational implementation behavior challenge the success of Football Fitness? European Journal for Sport and Society, 13:1, 19-37. DOI: $10.1080 / 16138171.2016 .1153879$

Bennike, S., Ottesen, L., Grønlund, K.R., Krustrup, B. \& Midtgaard, J. (2019a). The implementation of Football Fitness. Accepted.

Bennike, S., Storm, R., Wikman, J.M. \& Ottesen, L. (2019b). The Organisation of Club Football in Denmark - A contemporary Profile. Accepted.

Bergsgaard, N. A., Houlihan, B., Mangset, P., Nødland, S. I. \& Rommetvedt, H. (2007): Sport Policy - A comparative Analysis of Stability and Change. B.H. Oxford.

Bloyce, D. \& Smith, A. (2010). Sport policy and development - an introduction. Wiltshire: Routledge.

Campbell, J.L. (2004): Institutional Change and Globalization. Woodstock, Oxfordshire: Princeton University Press.

CHS, 2013: Seminar om fodbold og sundhed. https://www.holdspil.ku.dk/arrangementer/2013/seminar-fodbold-fitness/

Creswell, J.W. (2007): Qualitative Inquiry \& Research - Choosing Among Five Approaches. Thousand Oaks: Sage publications, Inc.

DBU(a): Pressemeddelelse: Fodbold som fitness. (2010)

DBU(b): Fodbold Fitness (motionsfodbold). (internt dokument) (2010)

DBU(c): Fodbold Fitness - Din sunde og fleksible mulighed. (2011)

DBU(d): PASSION, UDVIKLING, FALLESSKAB - Strategi for videreudviklingen af dansk fodbold til 2015. (2010)

DBU (2014): Millioner til motionsfodbold for voksne. https://www.dbu.dk/nyheder/2014/februar/millioner-til-motionsfodbold-for-voksne/

European Commission (2014): Sport and Physical Activity. Conducted by TNS Opinion \& Social. Lamprecht, M., Fischer, A., \& Stamm, H. (2014): Sport Schweiz 2014: Sportaktivität und Sportinteresse der Schweizer Bevölkerung. Observatorium Sport und Bewegung Schweiz c/o Lamprecht \& Stamm Sozialforschung und Beratung AG.

Fahlén, J., Eliasson, I. \& Wikman, K. (2015): Resisting self-regulation: an analysis of sport policy programme making and implementation in Sweden. International Journal of Sport Policy and Politics, 7:3, 391-406. DOI:10.1080/19406940.2014.925954

Fodboldfabrikken (2019): https://fodboldfabrikken.dk/vaelgcenter

Forum for Idræt (2011): Idræt og velfærdspolitik. 01. 2011. Red. Ottesen, L., \& Jakobsen, P. J., Forum for idræt, historie \& samfund.

Gammelsæter, H. \& Senaux, B. (2011): The Organisation and Governance of Top Football Across Europe - An Institutional Perspective. Routledge, Taylor \& Francis Group. New York, 2011. 
Grønkjær, A. \& Olsen, D. H. (2007): Fodbold, fair play og forretning - Dansk klubfodbolds historie. Turbine Forlaget, Århus.

Houlihan, B. (2005): Public Sector Sport Policy. Developing a Framework for Analysis. International review for the sociology of sport 40/2(2005) 163-185. DOI:10.1177/1012690205057193

Idan (2010): Over blik - Nyt fra Idan, Nr. 31, Juni 2010. http://www.idan.dk/media/\%7BAB95E57F-BB92-42Co-83A5-331E2288627E\%7D/ Nyhedsbrev31.pdf

Karp, S., Fahlén, J. \& Löfgren, K. (2014): More of the same instead of qualitative leaps: A study of inertia in the Swedish sports system. European Journal for Sport and Society 2014, 11 (3), 301-320. DOI:10.1080/16138171.2014.11687946

Lamprecht, M., Fischer, A., \& Stamm, H. (2014): Sport Schweiz 2014: Sportaktivität und Sportinteresse der Schweizer Bevölkerung [Sport Switzerland 2014: Sport activity and sport interest of the Swiss population]. Observatorium Sport und Bewegung Schweiz c/o Lamprecht \& Stamm Sozialforschung und Beratung AG.

Laub, T.B. (2013): Danskernes motions- og sportsvaner 2011. Idrættens Analyseinstitut.

Lynggaard, K. (2010): Dokumentanalyse. I: Brinkmann, S. \& Tanggaard, L. (red.) Kvalitative Metoder - En Grundbog. Hans Reitzels Forlag. Viborg.

Mahoney, J. (2000): Path Dependence in Historical Sociology. Theory and society, 29(4), $507-548$

Nichols, G. \& James, M. (2008): One size does not fit all: implications of sports club diversity for their effectiveness as a policy tool and for government support. Managing Leisure, 13:2, 104-114. DOI:10.1080/13606710801933461

Ottesen, L., Bennike, S. \& Thing, L.F. (2017). The emergence of the Danish Football Fitness concept. Proceedings of the $8^{\text {th }}$ World Congress on Science and Football.

Pedersen, L.K.; Ottesen, L.S.; Thing, L.F. (2019). Football Fitness as a meaningful male activity. International Review for the Sociology of Sport. Under review.

Pilgaard, M. \& Rask, S. (2016) Danskernes motions- og sportsvaner 2016. Idrættens Analyseinstitut.

Scheerder, J., Vandermeerschen, H., Van Tuyckom, C., Breedveld, K., \& Vos, S. (2011). Understanding the game: Sport participation in Europe. Facts, reflections and recommendations (Sport Policy \& Management 10). Leuven, Belgium: Katho lieke Universiteit Leuven.

Tiessen-Raaphorst, A. \& van den Dool, R. (2015): Sportdeelname [Sport participation]. In Tiessen- Raaphorst (ed.) Rapportage Sport 2014 [Sport Report 2014]. The Hague: The Netherlands Institute for Social Research.

SJMS (2010): Scandinavian Journal of Medicine \& Science in Sports, volume 20, supplement 1, April 2010: Football for Health - Prevention of Risk Factors for Non-communicable Diseases. 
Skille, E. (2008): Understanding Sport Clubs as Sport Policy Implementers - A theoretical Framework for the Analysis of the Implementation of Central Sport Policy through Local and Voluntary Sport Organizations. International Review for the sociology of Sport 43(2) 181-200. DOI:10.1177/1012690208096035

Skille, E. A. (2011): The conventions of sport clubs: enabling and constraining the implementation of social goods through sport. Sport, Education and Society, 16:2, 241-253. DOI:10.1080/13573322.2011.540430

Sydow, J., Schreyögg, G. \& Koch, J. (2005): Organizational Paths: Path Dependency and Beyond. 21 ${ }^{\text {st }}$. EGOS Colloquium, June 30- July 2, 2005, Berlin, Germany.

Thing, L.F. \& Ottesen, L. (2013). Young people's perspectives on health, risks and physical activity in a Danish secondary school. Health, Risk \& Society, 2013. DOI:10.1080/1369 8575.2013.802294

Thing, L.F., Hybholt, M.G., Jensen, A.L. \& Ottesen, L.S. 2016. Constraining and enabling possibilities for the management of leisure time for women. Annals of Leisure Research. DOI:10.1080/11745398.2016.1178153

Thing, L.F.; Ottesen, L.S. (2018). 'Football Fitness': - A quest for excitement or a leisure routinisation (chapter 4)? In: Figurational Research in Sport, Leisure and Health, Edited by Dominic Malcolm and Philippa Velija. Routledge.

Thing, L.F.; Hybholt, M.G.; Jensen, A.L.; Ottesen, L.S. (2019). 'Football Fitness for the sake of one's health? - The perspectives of female players'. Qualitative Research in Sport, Exercise and Health. DOI:10.1080/2159676X.2019.1595106

Tiessen-Raaphorst, A., \& van den Dool, R. (2015). Sportdeelname [Sport participation]. In Tiessen- Raaphorst (ed.) Rapportage Sport 2014 [Sport Report 2014]. The Hague: The Netherlands Institute for Social Research.

Vail, S.E. (2007): Community Development and Sport Participation. Journal of Sport Management, 21, 571-596. DOI:10.1123/jsm.21.4.571 


\section{SUMMARY}

The initiative of Football Fitness was launched by the Danish FA in 2011 in response to a number of developing trends in Danish sporting life, such as changes in the sporting habits of Danish adults (over 16 years of age) and an increasing political desire to involve association-based sport in public social and health provision. The Danish FA describes Football Fitness as football which "from both a sporting and organisational perspective innovatively breaks with the traditional organisation, administration and membership structure". This description is explored and challenged in this article, with a starting point in the theory of path-breaking concepts and the deployment of document studies. The results of the analysis show that Football Fitness departs from the sporting form of recreational football, but not with the organisational form. This is challenged in the article's discussion, which concludes that the degree of departure depends on the individual club's method of administering Football Fitness.

SØREN BENNIKE er Projektleder for 'Forskning og Viden' i Dansk Boldspil Union. Her sikrer han indsamling af relevant viden samt involvering og udbytte af forskningsprojekter med fodbold som omdrejningspunkt. Han er tidligere forsker på Institut for Idræt og Ernæring og Center for Holdspil og Sundhed. I 2016 fik han en Ph.d.-grad i humanistisk og samfundsfaglig idrætsvidenskab ved Institut for Idræt og Ernæring v. Københavns Universitet. Hans primære undervisnings- og forskningsområder knyttede sig idrætspolitik, idrætsorganisationer, implementering og innovation.

LAILA OTTESEN er Lektor på Institut for Idræt og Ernæring v. Københavns Universitet. Derudover sidder hun i styregruppen på Center for Holdspil og Sundhed og er President-Elect i European Association for Sociology of Sport. I 1995 fik hun en Ph.d.-grad i Europæisk Etnologi v. Københavns Universitet. Hendes primære forskningsområder knytter sig til idrætspolitik, idrætsorganisationer, forebyggelse og sundhedsfremme, implementering og innovation. Laila har stor erfaring med undervisning og har vejledt mere end 100 specialestuderende. 